\title{
Clinical evaluation of pregnant women with SARS-COV2 pneumonia: a real-life study from Egypt
}

Samy Zaky ${ }^{1}$, Hossam Hosny ${ }^{2}$, Gehan Elassal ${ }^{3}$, Noha Asem ${ }^{4}$, Amin Abdel Baki ${ }^{5}$, Ehab Kamal ${ }^{6}$, Akram Abdelbary $^{7}$, Ahmad Said ${ }^{7}$, Hamdy Ibrahim ${ }^{8}$, Khaled Taema ${ }^{7}$, Wagdy Amin', Sherief Abd-Elsalam ${ }^{10^{*}}$ (D, Shaimaa Soliman ${ }^{11}$, Hend Salah Abdelmenam ${ }^{12}$, Ahmed S. Mohamed ${ }^{13}$, Mohamed Elnady ${ }^{14}$, Mohamed Hassany ${ }^{5}$ and Hala Zaid ${ }^{9}$

\begin{abstract}
Background: Knowledge about the outcome of COVID-19 on pregnant women is so important. The published literature on the outcomes of pregnant women with COVID-19 is confusing. The aim of this study was to report our clinical experience about the effect of COVID-19 on pregnant women and to determine whether it was associated with increased mortality or an increase in the need for mechanical ventilation in this special category of patients.

Methods: This was a cohort study from some isolation hospitals of the Ministry of Health and Population, in eleven governorates, Egypt. The clinical data from the first 64 pregnant women with COVID-19 whose care was managed at some of the Egyptian hospitals from 14 March to 14 June 2020 as well as 114 non-pregnant women with COVID-19 was reviewed.

Results: The two groups did not show any significant difference regarding the main outcomes of the disease. Two cases in each group needed mechanical ventilation ( $p$ 0.617). Three cases (4.7\%) died among the pregnant women and two (1.8\%) died among the non-pregnant women ( $p$ 0.352).
\end{abstract}

Conclusions: The main clinical outcomes of COVID-19 were not different between pregnant and non-pregnant women with COVID-19. Based on our findings, pregnancy did not exacerbate the course or mortality of COVID-19 pneumonia.

Keywords: COVID-19, Pregnancy, Outcomes, Mortality, Egypt, Ventilation

\section{Introduction}

The virus that causes COVID-19 and the virus that caused the severe acute respiratory syndrome (SARS) outbreak in 2003 are genetically related to each other, but the diseases caused by them are completely different. SARS was more deadly but much less contagious than COVID-19 [1, 2]. COVID-19 is clinically milder than MERS or SARS in terms of severity and mortality (the death rate for COVID-19 appears to be around 2-5\% [1-4].

\footnotetext{
* Correspondence: sherif.abdelbaky@med.tanta.edu.eg

${ }^{10}$ Tropical Medicine and Infectious Diseases Department, Faculty of Medicine, Tanta University, Tanta, Egypt

Full list of author information is available at the end of the article
}

As cases of COVID-19 continue to rise in countries across the region, health systems face tremendous pressure to manage COVID-19 patients [1-8].

The published literature on the outcomes of pregnant women with COVID-19 is very confusing [6-17]. As of 20 April 2020, 51 papers have reported primary data on COVID-19 during pregnancy [6-32]. However, there were a lot of problems with these information sources. First, there was double counting of cases. This was a particular problem with early reports from China, and the authors rarely explained it. Second, most of the reports were of very small numbers; meanwhile; the larger studies reported few details. Another problem was that

\section{Springer Open}

() The Author(s). 2021 Open Access This article is licensed under a Creative Commons Attribution 4.0 International License, which permits use, sharing, adaptation, distribution and reproduction in any medium or format, as long as you give appropriate credit to the original author(s) and the source, provide a link to the Creative Commons licence, and indicate if changes were made. The images or other third party material in this article are included in the article's Creative Commons licence, unless indicated otherwise in a credit line to the material. If material is not included in the article's Creative Commons licence and your intended use is not permitted by statutory regulation or exceeds the permitted use, you will need to obtain permission directly from the copyright holder. To view a copy of this licence, visit http://creativecommons.org/licenses/by/4.0/. 
one third of these papers were individual case reports, which were likely biased toward severe or conditions without classical presentation.

Pregnant women are particularly vulnerable to respiratory pathogens and acute pneumonia, because they are in an immunosuppressed state, and additionally the adaptive physiological changes during pregnancy make them intolerant to hypoxia $[25,26]$. The aim of this study is to clinically evaluate the effect of COVID-19 on pregnant women and to determine whether it was associated with increased mortality or need for mechanical ventilation in this special category of patients.

\section{Methods}

\subsection{Study design and settings}

This was a cohort study from some isolation hospitals affiliated to the Ministry of Health and Population in 11 governorates in Egypt. We reviewed clinical data from the first 64 pregnant women with COVID-19 whose care was managed at these Egyptian hospitals from 14 March to 14 June 2020 as well as 114 non-pregnant women with COVID-19.

\subsection{Data collection methods}

All pregnant females were subjected to full history taking, clinical examination, and full-laboratory data.

The main outcomes were the difference in mortality rates and the need for mechanical ventilation.

The research was approved by the Ministry of Health and Population Research Ethics Committee. An informed consent was obtained from all participants in this research. Privacy of participants and confidentially of the data were assured. Risks and Benefits were declared.

\subsection{Statistical analysis}

Data were expressed in number (No.), percentage (\%) mean $(\overline{\mathrm{x}})$, and standard deviation (SD). Student's $t$ test was used for comparison of quantitative normally distributed variables between two groups, while MannWhitney's test was used for not normally distributed ones. Chi-square test $(\chi 2)$ was used to study association between qualitative variables. Whenever any of the expected cells were less than five, Fisher's exact test was used. A univariate logistic regression analysis was performed to ascertain the effects of possible risk factors on the final outcome. Two-sided $P$ value of $<0.05$ was considered statistically significant.

\section{Results}

The study included 64 pregnant women with mean gestational age of $10.73 \pm 2.15$ weeks. The mean age of the pregnant women was $34.93 \pm 6.27$ years with no significant difference from the non-pregnant group $(p=$
0.109). Among the pregnant COVID-19 patients, 9 (14.1) were in the first, 16 (25.0) in the second and 39 (60.9) in the third trimester. Four $(6.25 \%)$ of the pregnant group had hypertension, 3 (4.7\%) had diabetes mellitus and $4(6.25 \%)$ had other comorbidities including cancer, asthma, and rheumatic heart disease. There was no significant difference between the 2 groups regarding different comorbidities, percentage of oxygen saturation at presentation or disease severity $(p=0.700,0.206$, and 0.363 respectively) (Table 1 ).

The laboratory investigation did not show any significant difference between the two groups (Table 2).

The two groups did not show any significant difference regarding the main outcomes of the disease. Two cases in each group needed mechanical ventilation $(p=$ 0.617). Three cases $(4.7 \%)$ died among the pregnant women and two $(1.8 \%)$ died among the non-pregnant women $(p=0.352)$, (Table 3$)$

The univariate analysis showed that none of the possible risk factors was associated with the mortality among the studied patients including pregnancy (Table 4).

No statistically significant difference was noted among patients in different trimesters regarding the disease severity $(p=0.552)$. Four cases had severe COVID-19

Table 1 Comparison between the pregnant COVID-19 and nonpregnant COVID-19 patients regarding their clinical

characteristics, Egypt, 2020

\begin{tabular}{|c|c|c|c|}
\hline Variable & $\begin{array}{l}\text { Pregnant } \\
\text { COVID-19 }(n=64)\end{array}$ & $\begin{array}{l}\text { Non-pregnant } \\
\text { COVID-19 }(n=114)\end{array}$ & $P$ value \\
\hline Age (in years) & $34.93 \pm 6.27$ & $36.91 \pm 8.60$ & 0.109 \\
\hline \multicolumn{4}{|l|}{ Trimester } \\
\hline First & $9(14.1)$ & - & - \\
\hline Second & $16(25.0)$ & & \\
\hline Third & $39(60.9)$ & & \\
\hline \multicolumn{4}{|l|}{ Co-morbidities } \\
\hline No & $53(82.8)$ & $88(77.2)$ & 0.700 \\
\hline HTN & $4(6.25)$ & $11(9.6)$ & \\
\hline DM & $3(4.7)$ & $9(7.9)$ & \\
\hline Others & $4(6.25)$ & $6(5.3)$ & \\
\hline \multicolumn{4}{|l|}{$\mathrm{O} 2$ saturation } \\
\hline 100-95\% & $50(78.1)$ & $74(64.9)$ & 0.206 \\
\hline $95-90 \%$ & $6(9.4)$ & $23(20.2)$ & \\
\hline $90-85 \%$ & $5(7.8)$ & $8(7.0)$ & \\
\hline$<85 \%$ & $3(4.7)$ & $9(7.9)$ & \\
\hline \multicolumn{4}{|c|}{ Disease severity } \\
\hline Mild & $44(68.8)$ & 75 (65.8) & \\
\hline Moderate & $16(25.0)$ & 36 (31.6) & 0.363 \\
\hline Severe & $4(6.2)$ & $3(2.6)$ & \\
\hline
\end{tabular}

HTN hypertension, DM diabetes mellitus 
Table 2 Comparison between the pregnant COVID-19 and nonpregnant COVID-19 patients regarding their laboratory characteristics, Egypt, 2020

\begin{tabular}{llll}
\hline Variable & $\begin{array}{l}\text { Pregnant } \\
\text { COVID }(\boldsymbol{n}=64) \\
\text { Mean } \pm \text { SD }\end{array}$ & $\begin{array}{l}\text { Non-pregnant } \\
\text { COVID }(\boldsymbol{n}=114)\end{array}$ & Pean \pm SD \\
\hline Hb & $10.73 \pm 2.15$ & $11.23 \pm 1.54$ & 0.125 \\
WBCs & $7.34 \pm 3.11$ & $6.59 \pm 3.01$ & 0.116 \\
Lymphocytes & $11.13 \pm 14.65$ & $11.94 \pm 9.32$ & 0.653 \\
Neutrophils & $76.25 \pm 152.69$ & $74.89 \pm 139.34$ & 0.951 \\
Platelets & $245.42 \pm 114.78$ & $238.17 \pm 121.0$ & 0.696 \\
CRP & $16.67 \pm 27.06$ & $24.15 \pm 31.52$ & 0.085 \\
ALT & $26.25 \pm 53.51$ & $29.60 \pm 49.23$ & 0.673 \\
AST & $29.08 \pm 43.88$ & $28.00 \pm 14.66$ & 0.131 \\
Creatinine & $0.68 \pm 0.46$ & $0.82 \pm 1.09$ & 0.664 \\
Albumin & $3.17 \pm 6.87$ & $3.24 \pm 5.18$ & 0.938 \\
D dimer & $21.06 \pm 117.49$ & $46.42 \pm 241.15$ & 0.285 \\
Serum ferritin & $320.85 \pm 223.32$ & $360.78 \pm 509.82$ & 0.186 \\
\hline
\end{tabular}

infection; they were all in the 3rd trimester. No severe cases were reported in the 1st or 2nd trimesters. Although all the maternal deaths occurred in the 3rd trimester, this was not statistically significant $(p=0.715)$ (Table 5).

Among all the pregnant patients, two cases (3.1\%) had intrauterine fetal death (IUFD), one baby was born with hydrocephalus (1.6\%) and one (1.6\%) was born pre-term. There was no significant association between the trimester and the fetal outcome $(p=0.406)$ (Table 5).

\section{Discussion}

This study included 64 pregnant women with mean gestational age of $10.73 \pm 2.15$ weeks. There was no significant difference between the 2 groups regarding different comorbidities or percentage of oxygen saturation at presentation ( $p=0.700$ and 0.206 respectively). So, both groups were not significantly different regarding the baseline demographic criteria or regarding the presence of comorbid diseases.

Table 3 Comparison between the pregnant COVID-19 and nonpregnant COVID-19 patients regarding the main clinical diseaseoutcomes, Egypt, 2020

\begin{tabular}{llll}
\hline Variable & $\begin{array}{l}\text { Pregnant } \\
\text { COVID }(\boldsymbol{n}=64) \\
\text { no. (\%) }\end{array}$ & $\begin{array}{l}\text { Non-pregnant } \\
\text { COVID }(\boldsymbol{n}=114) \\
\text { no. }(\%)\end{array}$ & $P$ value \\
\hline $\begin{array}{l}\text { Need for } \\
\text { mechanical } \\
\text { ventilation }\end{array}$ & $2(3.2)$ & $2(1.8)$ & 0.617 \\
$\begin{array}{l}\text { Mortality } \\
\text { Died }\end{array}$ & $3(4.7)$ & & \\
\multicolumn{1}{c}{ Survived } & $61(95.3)$ & $2(1.8)$ & 0.352 \\
\hline
\end{tabular}

Table 4 Univariate analysis of possible risk factors associated with patients' mortality in the studied groups, Egypt, 2020

\begin{tabular}{lllll}
\hline Factor & \multicolumn{4}{l}{ Univariate analysis } \\
\cline { 2 - 5 } & $\begin{array}{l}\boldsymbol{P} \\
\text { value }\end{array}$ & OR & $\mathbf{9 5 \% \mathrm { Cl }}$ \\
\cline { 3 - 5 } & 0.425 & 0.953 & 0.846 & 1.073 \\
\hline Age & 0.779 & 1.174 & 0.383 & 3.600 \\
O2 saturation & 0.904 & 1.002 & 0.969 & 1.036 \\
ALT & 0.830 & 1.249 & 0.163 & 9.580 \\
Creatinine & 0.341 & 1.003 & 0.997 & 1.009 \\
Ferritin & 0.074 & 0.977 & 0.953 & 1.002 \\
CRP & 0.987 & - & - & - \\
D dimer & 0.731 & 0.676 & 0.073 & 6.296 \\
Presence of & & & & \\
comorbidity & 0.274 & 0.363 & 0.059 & 2.23 \\
Pregnancy & & & & \\
\hline
\end{tabular}

Interestingly, the two groups did not show any significant difference regarding the main outcomes of the disease. These results indicate that the main clinical outcomes of COVID-19 were not different between pregnant and non-pregnant women with COVID-19.

The National Institute of Health (NIH) (2020) reported that surveillance data released by the CDC in June 2020 showed that COVID-19-related death rates were similar in the pregnant and non-pregnant populations. Pregnancy outcomes such as preterm birth or pregnancy loss were not evaluated [28]. This report agrees with our conclusion that the mortality risks were similar among pregnant and non-pregnant women with COVID-19 infection.

On the other side, an Iranian case series reported maternal deaths in seven pregnant women among nine pregnant women who were infected with the novel coronavirus [29]. This was extremely different from our

Table 5 Maternofetal clinical features and outcome among different trimesters, Egypt, 2020

\begin{tabular}{|c|c|c|c|c|}
\hline Clinical feature & $\begin{array}{l}\text { 1st trimester } \\
(n=9) \\
\text { No. }(\%)\end{array}$ & $\begin{array}{l}\text { 2nd trimester } \\
(n=16) \\
\text { No (\%) }\end{array}$ & $\begin{array}{l}\text { 3rd trimester } \\
(n=39) \\
\text { No. }(\%)\end{array}$ & $P$ value \\
\hline \multicolumn{5}{|l|}{$\begin{array}{l}\text { Disease } \\
\text { severity }\end{array}$} \\
\hline Mild & $7(77.8)$ & $11(68.8)$ & $26(66.6)$ & 0.552 \\
\hline Moderate & $2(22.2)$ & $5(31.2)$ & $9(23.1)$ & \\
\hline Severe & $0(0.0)$ & $0(0.0)$ & $4(10.3)$ & \\
\hline $\begin{array}{l}\text { Maternal } \\
\text { deaths }\end{array}$ & $0(0.0)$ & $0(0.0)$ & $3(7.7)$ & 0.715 \\
\hline \multicolumn{5}{|l|}{$\begin{array}{l}\text { Fetal } \\
\text { outcome }\end{array}$} \\
\hline IUFD & $1(11.1)$ & $0(0.0)$ & $1(2.6)$ & 0.406 \\
\hline Hydrocephalus & $0(0.0)$ & $1(6.3)$ & $0(0.0)$ & \\
\hline Preterm labor & $0(0.0)$ & $1(6.3)$ & $0(0.0)$ & \\
\hline
\end{tabular}


findings. However, and generally speaking, individual case reports were likely biased toward severe or unusual disease.

\subsection{Limitations of the study}

The main limitation of the study is the short time of the outcome, therefore, further studies about the long-term outcomes for the newborn and whether mother-to-child transmission are required. Nevertheless, the data in this study allow for better understanding of the clinical outcomes of COVID-19 infection in pregnancy and whether they were different between pregnant and non-pregnant females. Further studies discussing the follow-up of recovered pregnant women and the impact on their babies, type of delivery, and puerperium are highly recommended.

\section{Conclusions}

The main clinical outcomes of COVID-19 were not different between pregnant and non-pregnant women with COVID-19. Based on our findings, pregnancy did not exacerbate the course or mortality of COVID-19 pneumonia.

\section{Abbreviations}

Alb: Albumin; ALT: Alanine transaminase; AST: Aspartate transaminase; BMI: Body mass index; CBC: Complete blood count; COVID: Coronavirus infectious disease; CRP: C-reactive protein; DM: Diabetes mellitus; Hb: Hemoglobin; HBV: Hepatitis B virus; HCV: Hepatitis C virus; HTN: Hypertension; No: Number; PCR: Polymerase chain reaction; PLT: Platelets; SARS: Serious acute respiratory distress syndrome; SD: Standard deviation; SVR: Sustained virological response; USA: United States of America; WBCs: White blood cells

\section{Acknowledgements}

The authors acknowledge all patients who participated in this study and take responsibility for all aspects of the reliability and freedom from bias of the data presented and their discussed interpretation.

\section{Authors' contributions}

SZ, SA-E, and HZ designed the study. NA and SS developed the methodology, SZ and SA-E wrote the manuscript. SZ, HH, GE, NA, AAB, EK, AA, AS, HI, KT, WA, SA-E, HSA, ASM, ME, and MH collected the data. All the authors participated sufficiently in the work, read, and approved the final version of the manuscript.

\section{Funding}

This research received no specific grant from any funding agency in the public, commercial, or not-for-profit sectors.

\section{Availability of data and materials}

Data will be available from the authors on reasonable request.

\section{Declarations}

\section{Ethics approval and consent to participate}

The research was approved by the Research Ethics Committee of Tanta University, Faculty of Medicine with approval code 33966/7/20. The research was also approved by the Research Ethics Committee of the Ministry of Health and Population. An informed written consent was obtained from each patient. The study protocol complies with the ethical guidelines of the 1975 Declaration of Helsinki as reflected in prior approval by the institution's Human Research Committee.

\section{Consent for publication}

Not applicable.

\section{Competing interests}

The authors declare that there is no conflict of interest.

\section{Author details}

Hepatogastroenterology and Infectious Diseases Department, Faculty of Medicine, Al-Azhar University, Cairo, Egypt. ²Chest Diseases Department, Head of Pulmonary Hypertension Unit, Faculty of Medicine, Cairo University, Cairo, Egypt. ${ }^{3}$ Pulmonary Medicine Department, Faculty of Medicine, Ain Shams University, Cairo, Egypt. ${ }^{4}$ Public Health Department, Faculty of Medicine, Cairo University, Cairo, Egypt. ${ }^{5}$ National Hepatology and Tropical Medicine Research Institute (NHTMRI), Cairo, Egypt. ${ }^{6}$ Tropical Medicine Department. Medical Division, National Research Center, Cairo, Egypt. ${ }^{7}$ Critical Care Medicine Department, Faculty of Medicine, Cairo University, Cairo, Egypt. ${ }^{8}$ Fever Hospitals, Ministry of Health and Population (MOHP), Cairo, Egypt. ${ }^{9} \mathrm{MOHP}$, Cairo, Egypt. ${ }^{10}$ Tropical Medicine and Infectious Diseases Department, Faculty of Medicine, Tanta University, Tanta, Egypt. ${ }^{11}$ Public Health and Community Medicine Department, Menoufia University, Menoufia, Egypt. ${ }^{12}$ Obstetrics and Gynecology Department, Al Zahraa University Hospital, Cairo, Egypt. ${ }^{13}$ Chest Diseases Department, Faculty of Medicine, Tanta University, Tanta, Egypt. ${ }^{14}$ Pulmonology Department, Faculty of Medicine, Cairo University, Cairo, Egypt.

Received: 2 December 2020 Accepted: 18 October 2021

Published online: 04 November 2021

\section{References}

1. Chen N, Zhou M, Dong X, Qu J, Gong F, Han Y, et al. Epidemiological and clinical characteristics of 99 cases of 2019 novel coronavirus pneumonia in Wuhan, China: a descriptive study. Lancet. 2020;395(10223):507-13. https:// doi.org/10.1016/S0140-6736(20)30211-7.

2. World Health Organization. Infection prevention and control during health care when COVID-19 is suspected. 2020. https://www.who.int/publicationsdetail/infection-prevention-and-control-during-health-care-when-novelcoronavirus-(ncov)-infection-is-suspected. Accessed 19 Mar 2020.

3. Bootsma MC, Ferguson NM. The effect of public health measures on the 1918 influenza pandemic in U.S. cities. Proc Natl Acad Sci USA. 2007;104(18): 7588-93. https://doi.org/10.1073/pnas.0611071104.

4. Desouky E. Prediction of the epidemic peak of Covid19 in Egypt. medRxiv. 2020:2020.04.30.20086751 https://doi.org/10.1101/2020.04.30.20086751.

5. Pastick KA, Nicol MR, Smyth E, Zash $R$, Boulware DR, Rajasingham $R$, et al. A systematic review of treatment and outcomes of pregnant women with COVID-19-A call for clinical trials. Open Forum Infect Dis. 2020;7(9):ofaa350. https://doi.org/10.1093/ofid/ofaa350.

6. Khalil A, Kalafat E, Benlioglu C, O'Brien P, Morris E, Draycott T, et al. SARSCoV-2 infection in pregnancy: A systematic review and meta-analysis of clinical features and pregnancy outcomes. EClin Med. 2020;25:100446. https://doi.org/10.1016/j.eclinm.2020.100446.

7. Wenling $Y$, Junchao Q, Xiao Z, Ouyang S. Pregnancy and COVID-19: management and challenges. Rev Inst Med Trop Sao Paulo. 2020;62:e62. https://doi.org/10.1590/s1678-9946202062062.

8. Liu F, Liu H, Hou L, Li J, Zheng H, Chi R, et al. Clinico-radiological features and outcomes in pregnant women with COVID-19 pneumonia compared with age-matched non-pregnant women. Infect Drug Resist. 2020;13:284554. https://doi.org/10.2147/IDR.S264541.

9. Ronnje L, Länsberg JK, Vikhareva O, Hansson SR, Herbst A, Zaigham M. Complicated COVID-19 in pregnancy: a case report with severe liver and coagulation dysfunction promptly improved by delivery. BMC Pregnancy Childbirth. 2020;20(1):511. https://doi.org/10.1186/s12884-020-03172-8.

10. Borges do Nascimento IJ, von Groote TC, O'Mathúna DP, Abdulazeem HM, Henderson C, Jayarajah U, et al. Clinical, laboratory and radiological characteristics and outcomes of novel coronavirus (SARS-CoV-2) infection in humans: a systematic review and series of meta-analyses. PLoS One. 2020; 15(9):e0239235. https://doi.org/10.1371/journal.pone.0239235.

11. Tug N, Yassa M, Köle E, Sakin Ö, Çakır Köle M, Karateke A, et al. Pregnancy worsens the morbidity of COVID-19 and this effect becomes more prominent as pregnancy advances. Turk J Obstet Gynecol. 2020;17(3):14954. https://doi.org/10.4274/tjod.galenos.2020.38924.

12. Han Y, Ma H, Suo M, Han F, Wang F, Ji J, et al. Clinical manifestation, outcomes in pregnant women with COVID-19 and the possibility of vertical transmission: a systematic review of the current data. J Perinat Med. 2020; 48(9):912-24. https://doi.org/10.1515/jpm-2020-0431.

13. Afshar Y, Gaw SL, Flaherman VJ, Chambers BD, Krakow D, Berghella V, et al. Clinical presentation of Coronavirus disease 2019 (COVID-19) in pregnant 
and recently pregnant people. Obstet Gynecol. 2020;136(6):1117-25. https:// doi.org/10.1097/AOG.0000000000004178.

14. Simsek Y, Ciplak B, Songur S, Kara M, Karahocagil MK. Maternal and fetal outcomes of COVID-19, SARS, and MERS: a narrative review on the current knowledge. Eur Rev Med Pharmacol Sci. 2020;24(18):9748-52. https://doi. org/10.26355/eurrev 202009_23068.

15. Menezes MO, Takemoto MLS, Nakamura-Pereira M, Katz L, Amorim MMR, Salgado HO, et al. Risk factors for adverse outcomes among pregnant and postpartum women with acute respiratory distress syndrome due to COVID19 in Brazil. Int J Gynaecol Obstet. 2020;151(3):415-23. https://doi.org/10.1 002/ijgo.13407.

16. Figueiro-Filho EA, Yudin M, Farine D. COVID-19 during pregnancy: an overview of maternal characteristics, clinical symptoms, maternal and neonatal outcomes of 10,996 cases described in 15 countries. J Perinat Med. 2020;48(9):900-11. https://doi.org/10.1515/jpm-2020-0364 PMID: 33001856.

17. Alay I, Yildiz S, Kaya C, Yasar KK, Aydin OA, Karaosmanoglu HK, et al. The clinical findings and outcomes of symptomatic pregnant women diagnosed with or suspected of having coronavirus disease 2019 in a tertiary pandemic hospital in Istanbul, Turkey. J Obstet Gynaecol Res. 2020. https:// doi.org/10.1111/jog.14493.

18. Marín Gabriel MA, Reyne Vergeli M, Caserío Carbonero S, Sole L, Carrizosa Molina T, Rivero Calle I, et al. Maternal, perinatal and neonatal outcomes with COVID-19: a multicenter study of 242 pregnancies and their 248 infant newborns during their first month of life. Pediatr Infect Dis J. 2020;39(12): e393-7. https://doi.org/10.1097/INF.0000000000002902.

19. Li W, Yu N, Kang Q, Zeng W, Deng D, Chen S, et al. Clinical manifestations and maternal and perinatal outcomes with COVID-19. Am J Reprod Immunol. 2020;84(5):e13340. https://doi.org/10.1111/aji.13340.

20. Pirjani R, Hosseini R, Soori T, Rabiei M, Hosseini L, Abiri A, et al. Maternal and neonatal outcomes in COVID-19 infected pregnancies: a prospective cohort study. J Travel Med. 2020;27(7):taaa158. https://doi.org/10.1093/jtm/taaa158.

21. Diriba K, Awulachew E, Getu E. The effect of coronavirus infection (SARS-COV-2, MERS-COV, and SARS-COV) during pregnancy and the possibility of vertical maternal-fetal transmission: a systematic review and meta-analysis. Eur J Med Res. 2020;25(1):39. https://doi.org/10.1186/ s40001-020-00439-w.

22. Allotey J, Stallings E, Bonet M, Yap M, Chatterjee S, Kew T, et al. Clinical manifestations, risk factors, and maternal and perinatal outcomes of coronavirus disease 2019 in pregnancy: living systematic review and metaanalysis. BMJ. 2020;370:m3320. https://doi.org/10.1136/bmj.m3320.

23. Kucirka LM, Norton A, Sheffield JS. Severity of COVID-19 in pregnancy: a review of current evidence. Am J Reprod Immunol. 2020;84(5):e13332. https://doi.org/10.1111/aji.13332.

24. Turan O, Hakim A, Dashraath P, Jeslyn WIL, Wright A, Abdul-Kadir R. Clinical characteristics, prognostic factors, and maternal and neonatal outcomes of SARS-CoV-2 infection among hospitalized pregnant women: a systematic review. Int J Gynaecol Obstet. 2020;151(1):7-16. https://doi.org/10.1002/ ijgo.13329.

25. Chen H, Guo J, Wang C, Luo F, Yu X, Zhang W, et al. Clinical characteristics and intrauterine vertical transmission potential of COVID-19 infection in nine pregnant women: a retrospective review of medical records. Lancet. 2020;395(10226):809-15. https://doi.org/10.1016/S0140-6736(20)30360-3 Erratum in: Lancet. 2020 Mar 28; 395(10229):1038. Erratum in: Lancet. 2020 Mar 28; 395(10229):1038.

26. Corman VM, Landt O, Kaiser M, Molenkamp R, Meijer A, Chu DK, et al. Detection of 2019 novel coronavirus (2019-nCoV) by real-time RT-PCR. Euro Surveill. 2020;25(3):2000045. https://doi.org/10.2807/1560-7917.ES.2020.25.3.2 000045 Erratum in: Euro Surveill. 2020 Apr;25(14): Erratum in: Euro Surveill. 2020 Jul;25(30): Erratum in: Euro Surveill. 2021 Feb;26(5).

27. Jamieson DJ, Honein MA, Rasmussen SA, Williams JL, Swerdlow DL, Biggerstaff MS, et al. H1N1 2009 influenza virus infection during pregnancy in the USA. Lancet. 2009;374(9688):451-8. https://doi.org/10.1016/50140-673 6(09)61304-0.

28. National Institutes of Health. COVID-19 treatment guidelines panel. Coronavirus disease 2019 (COVID-19) treatment guidelines. https://www covid19treatmentguidelines.nih.gov/. Accessed 2 Sept 2020.

29. Hantoushzadeh S, Shamshirsaz AA, Aleyasin A, Seferovic MD, Aski SK, Arian SE, et al. Maternal death due to COVID-19. Am J Obstet Gynecol. 2020; 223(1):109.e1-e16. https://doi.org/10.1016/j.ajog.2020.04.030.
30. Santhosh J, Al Salmani M, Khamis F, Ali Al Ubaidani S, Al-Zakwani I. Clinical characteristics of COVID-19 in pregnant women: a retrospective descriptive single-center study from a tertiary hospital in Muscat, Oman. Int J Gynaecol Obstet. 2021;152(2):270-4. https://doi.org/10.1002/ijgo.13427.

31. Papageorghiou AT, Deruelle P, Gunier RB, Rauch S, García-May PK, Mhatre $M$, et al. Preeclampsia and COVID-19: results from the INTERCOVID prospective longitudinal study. Am J Obstet Gynecol. 2021;225(3):289.e1e17. https://doi.org/10.1016/j.ajog.2021.05.014.

32. Villar J, Ariff S, Gunier RB, Thiruvengadam R, Rauch S, Kholin A, et al. Maternal and neonatal morbidity and mortality among pregnant women with and without COVID-19 infection: the INTERCOVID multinational cohort study. JAMA Pediatr. 2021;175(8):817-26. https://doi.org/10.1001/jamapedia trics.2021.1050.

\section{Publisher's Note}

Springer Nature remains neutral with regard to jurisdictional claims in published maps and institutional affiliations.

\section{Submit your manuscript to a SpringerOpen ${ }^{\circ}$ journal and benefit from:}

- Convenient online submission

- Rigorous peer review

- Open access: articles freely available online

High visibility within the field

- Retaining the copyright to your article

Submit your next manuscript at $\boldsymbol{\nabla}$ springeropen.com 